\title{
Production of lipase from Aspergillus oryzae (T4) isolate by solid- state fermentation
}

\author{
إنتاج إنزيم اللايبيزمن العزلة Aspergillus oryza (T4) بطريقة تخمرات الحالة الصلبة
}

Thikra A. Mustafa Shatha S.AL-Azawi* Khulood W.AL-Samarraei**

Biology Department/ Collage of Science for Women

*Biology Department/ Collage of Science

**Biotechnology Department/ AL-Nahrain University

\section{Absrtract}

Forty five fungal isolates belong to different species were tested for their ability to produce lipase, one of these isolates was selected as the best lipase producer. It was identified as a strain of Aspergillus oryzae (T4).

The optimum conditions for the production of lipase by solid-state fermentation included culturing of the fungus on cotton seed meal hydrated with $1 \%$ ammonium sulfate and1\% olive oil, pH 7.0 with $1: 2(\mathrm{w} / \mathrm{v})$ hydration ratio incubated at $30^{\circ} \mathrm{C}$ for 7 days .The best extraction solution for the enzyme was $0.2 \mathrm{M}$ phosphate buffer $\mathrm{pH}$ 7.0, the productivity reached $2 \mathrm{U} / \mathrm{g}$ dry weight under these conditions.

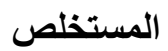

اختبرت قابلية خمس واربعون عزله فطريه محليه تعود لأنواع مختلفة على إنتاج إنزيم اللابيز وانتخبت واحده من هذه العزلات كأفضل عزله منتجه للأنزيم ، واظهر التثخيص على أنها إحدى سلالات Aspergillus oryza.

وجد إن الظروف المثلى لانتاج أنزيم اللابيز هي تنمية العفن على وسط التخمر الصلب المتكون من بذور القطن المرطبة بـ 1\% كبريتات الأمونيوم و1\% زيت الزيتون برقم هيدروجيني ابتدائي 7 ونسبة ترطيب 2:1 (وزن/ حجم) وحضنها بلرجة 37 م لمدة 7 أيام ، وكان افضل محلول لاستخلاص الأنزيم هو 0.2 مولار من دارىء الفوسفات برقم هيدروجيني 7 وبلغت إنتاجية الأنزيم (2وحدة/ غم) تحت هذه الظروف . 


\section{Introduction}

Lipases (Triacylglycerol acylhydrolase E.C.3.1.1.3) have potential application in food, leather, oil, chemical and pharmaceutical industries [1]. They are widely found in various animals, plants and microorganisms [2], microbial enzymes have many advantages, since the microorganisms can easily grown and usually not difficult to scale up the production conditions [3].

Most studies utilized the liquid media for lipase production from different microorganisms, there are few studies about the production of lipase by solid -state

\section{Materials and Methods}

\section{1-Czapek -Dox agar (merk)}

\section{2- Lipase detection medium}

-Rhan medium [5]

It contains: $5 \mathrm{~g} \mathrm{~K}_{2} \mathrm{HPO}_{4}, 5 \mathrm{~g}\left(\mathrm{NH}_{4}\right) 2 \mathrm{PO}_{4}, 1 \mathrm{~g}$ $\mathrm{MgSO}_{4} .7 \mathrm{H}_{2} \mathrm{O}, 1 \mathrm{~g} \mathrm{CaC} 2.6 \mathrm{H}_{2} \mathrm{O}, \mathrm{FeCl} .6 \mathrm{H}_{2} \mathrm{O}$ Trase, $15 \mathrm{~g}$ agar, 1L D.W. and $1 \%$ of sterilized olive oil was added after sterilization.

\section{3-Lipase production media}

\section{1- Tauson medium [5]}

It contains: $1 \mathrm{~g} \mathrm{~K} \mathrm{~K}_{2} \mathrm{HPO}_{4}, 2 \mathrm{~g} \mathrm{NaNO}_{3}, 0.5 \mathrm{~g}$ $\mathrm{KCl}, 0.5 \mathrm{~g} \mathrm{MgSO}_{4} .7 \mathrm{H}_{2} \mathrm{O}, 0.001 \mathrm{~g} \mathrm{FeSO}_{4}, 1 \%$ tween $80,15 \mathrm{~g}$ agar, 1L D.W. and $1 \%$ of fermentation . The aims of this study were to select a high lipase production fungal isolate, production of lipase in solid-state fermentation (SSF) and studying the effect of some conditions on lipase production, since this technique (SSF) has many economical and technical advantages as high productivity, higher product concentration, simpler equipment, lower contamination and the use of low cost substrates as agroindustry substrates [4]

sterilized olive oil was added after sterilization.

\section{2- Solid -Slate fermentation media}

Wheat bran, rice bran and corn bran were obtained from General Company of Grains. Cotton seed meal, corn seed meal and sunflower seed meal were obtained from General Company of Vegetable oils. These materials were used as substrates for SSF, $10 \mathrm{~g}$ of each material was hydrated with $30 \mathrm{ml}$ of hydration solution, (as described in the methods), in $250 \mathrm{ml}$ conical flasks, the $\mathrm{pH}$ was adjusted to 7.0 with $1 \mathrm{~N} \mathrm{NaOH}$ or $1 \mathrm{~N} \mathrm{HCl}$ and autoclaved at $121^{\circ} \mathrm{C}$ for $15 \mathrm{~min}$. 


\section{4-Source of isolates}

The fungal isolates, used in this study, were obtained from Biology Department/College of Science/University of Baghdad, General Company of Grains Ministry of Trade and Biotechnology Department/College of Science/Al-Nahrain University. The fungal isolates were activated and maintained on Czapek-Dox agar slants at $4^{\circ} \mathrm{C}$.

\section{5-Detection of lipase production}

Fungal isolates were grown on Rhan medium, the plates were incubated at $32^{\circ} \mathrm{C}$ for $72 \mathrm{hrs}$, the growth and white precipitate was observed.as an induction for lipase production

\section{6- Screening isolates for lipase production on SSF}

The fungal isolates were cultured on wheat bran medium, Hydrated with tap water and incubated at $32^{\circ} \mathrm{C}$ for $72 \mathrm{hrs}$. The enzyme was extracted with $40 \mathrm{ml}$ of tap water, the extract was filtered through a cloth and centerfuged at $6000 \mathrm{rpm}$ at $10^{\circ} \mathrm{C}$ for $30 \mathrm{~min}$.

\section{7- Determination of lipase activity}

Lipase activity was estimated according to the method of Bier [6] with some modification, $10 \mathrm{~g}$ of olive oil was emulsified by adding to $100 \mathrm{ml}$ of $3 \%$ aqueous solution of polyvinyl alcohol and homogenized in blender for $5 \mathrm{~min}$, the $\mathrm{pH}$ was adjusted to $8.5,1 \mathrm{ml}$ of crude enzyme was added to $9 \mathrm{ml}$ of emulsified substrate in $100 \mathrm{ml}$ of Erlenmeyer flask and incubated in shaker incubator at $100 \mathrm{rpm}$ at $37^{\circ} \mathrm{C}$ for $30 \mathrm{~min}$, the reaction mixture was stopped with ethanol-aceton 50:50(v/v) the mixture was titrated with $0.05 \mathrm{NaOH}$. One unit of lipase activity was defined as the amount of enzyme which release $1 \mathrm{~mol}$ of fatty acids per min under the determination condition.

8-Optimum conditions for lipase production

\section{8-1 pH and temperature}

The method of Grajek [7] was used to determine the optimum $\mathrm{pH}$ and temperature for lipase production, Tauson medium was prepared at different pHs (5-10) and incubated at different temperatures (26$40^{\circ} \mathrm{C}$ ), a disk of each fungal isolate was transferred to the medium surface and incubated for $72 \mathrm{hrs}$. The diameter of fungal colonies and lipolytic region were measured.

\section{8-2 Hydration solution}

Wheat bran was hydrated with different hydration solutions $1 \%$ ammonium sulphate, $1 \%$ ammonium sulphate with $1 \%$ sterilized olive oil and tap water and inoculated with $10^{5}$ spores/g wet weight and incubated at $30^{\circ} \mathrm{C}$ for $72 \mathrm{hrs}$ the enzyme activity was determined. 


\section{8-3 Lipase production media}

The solid substrate media described in 3-2 were hydrated with $1 \%$ ammonium sulphate with $1 \%$ sterilized olive oil, inoculated with $10^{5}$ spores/g wet weight and incubated at $30^{\circ} \mathrm{C}$ for $72 \mathrm{hrs}$, the enzyme was extracted and the activity was determined .

\section{8-4 Hydration ratio}

The substrate was hydrated with $1 \%$ ammonium sulphate with $1 \%$ olive oil at different ratios 1:1-1:4 (w/v) and incubated at $30^{\circ} \mathrm{c}$ for $72 \mathrm{hrs}$, the enzyme was extracted and the activity was assayed.

\section{Results}

\section{1-Screening of lipase producing fungi}

Forty five fungal isolates including different genera were screened, all isolates were found to be able to produce lipase but at various levels. Twenty one of them showed heavy growth with dense precipitation in lipase production medium, these isolates were considered as efficient lipase producers. Most of them (85\%) was found belong to Aspergillus and others belong to Penicillium, Table (1).

\section{2-production of lipase in solid state fermentation medium}

Six fungal isolates of different genera were selected according to their lipase activity on Rhan medium and grown in solid state

\section{8-5 Incubation period}

The cotton seed meal was hydrated with $1 \%$ ammonium sulphate with $1 \%$ olive oil and incubated at $30^{\circ} \mathrm{C}$ for $1-10$ days, two flasks per day were extracted and the enzyme activity was assayed.

\section{8-6 Extraction solution}

Different extraction solutions includes tap water, $0.2 \mathrm{M}$ sodium phosphate buffer, $0.1 \mathrm{M}$ sodium phosphate buffer, $0.1 \mathrm{M}$ sodium chlorid and $0.2 \mathrm{M}$ sodium chloride were used

fermentation medium (wheat bran), T4 and R2 isolates showed higher enzyme activity. It was found that maximum productivity of these isolates were reached to $(1.2 \mathrm{U} / \mathrm{g})$ of dry weight fig (1).

Wheat bran medium is a suitable substrate for production of different industrial enzymes such as amylase [8] proteases [9] since it contain the nutritional factor necessary for growth of microorganisms such as carbon and nitrogen. In other study wheat bran used to compare between lipase and protease production from different fungi including the genera Aspergillus, Geotricum, Mucor, Penicillum and Rhizopus, high lipolytic activity was appeared from 
Penicillum candidum, Mucor miehei and Penicillum camembertii than other isolates [10] .

\section{3-Determination of the optimum} conditions for lipase production

\section{3-1 pH}

To study effect of $\mathrm{pH}$ on growth as well as production ability of the isolate. Three fungal isolates were selected in accordance to their enzyme productivity. It was found that Aspergillus $\mathrm{R} 2$ isolate grows well at $\mathrm{pH}$ (6-9). The optimum $\mathrm{pH}$ for growth and lipase production for Penicillum P3.4 was (5-7) and Aspergillus T4 isolate favored $\mathrm{pH}$ (7-8) for growth and lipase production, Table (2).

In general, $\mathrm{pH}$ can influence growth and product formation due to its effect on the solubility of nutrients, ionization of the substrate and its availability to the microorganisms [11].

\section{3-2 Temperature}

It was found that optimum temperature for growth and lipase production from Penicillum P3.4 was $28^{\circ} \mathrm{C}$, while Aspergillus R2 and Aspergillus T4 isolates favored (28$30^{\circ} \mathrm{C}$ ). All isolates could not grow or produce lipase at $40^{\circ} \mathrm{c}$, Table (3).

\section{3-3 Hydration solution}

The results showed that $1 \%$ ammonium sulphate with $1 \%$ olive oil is more suitable for hydration of wheat bran as solid substrate fermentation medium figure (2) this may be attributed to inhibition of protease by ammonium sulphate since most microorganisms secrete proteases to degrade the complex protein to simple nitrogen compound and most proteases undergo catabolic repression i.e., the production of protease is repressed by simple nitrogen source [12] and hence the stability of lipase increases in the presence of ammonium sulphate .

Olive oil may induce lipase production since the production of inducible enzymes increase when this substrate found in the medium which behaves as inducer compound for enzyme production [13].

T4 isolate selected as efficient lipase producer, in addition to its rapid growth, this isolates was identified as Aspergillus oryzae according to criteria described by [14]. Aspergillus oryzae was recognized as the most widly exploited source of fungal enzyme [15]. Also, Apergillus oryzae is classified as Generally Regarded As Safe (GRAS) by FAD (non toxic microorganisms) and allow to be used in many industries such as food industry [16].

3-4 Production of lipase from Aspergillus oryzae $\mathbf{T} 4$ in different solid fermentation substrate media 
All solid fermentation substrate media used in this study was found support fungal growth .However, maximum lipase production was observed in cotton seed meal medium (1.6U/g), figure (3).

In general Solid fermentation substrate media considered as suitable media for fungal growth. Since they contain nutritional factors in sufficient quantity, they permits better air circulation among their particles and mycelial penetration, furthermore they are cheap, available and hence economic for the enzyme production.

\section{3-5 Hydration ratio}

Higher enzyme productivity from T4 isolate was obtained when the medium was hydrated with ratio 1:2 (w/v). The productivity reached $(2 \mathrm{U} / \mathrm{g})$ of dry weight, while decreased to $(1.3 \mathrm{U} / \mathrm{g})$ and to $(0.64 \mathrm{U} / \mathrm{g})$ when the hydration was increased to $1: 3$ and 1:4 (w/v) respectively, figure (4).
The moisture level in solid substrate fermentation may vary depending on the substrate. Generally, the ratio of water to substrate in solid substrate fermentation ranged between 1:1-1:10 (w/v) [3].

\section{3-6 Incubation time}

The productivity of lipase increased with increasing the incubation period till the seventh day in which it reached the maximum level, figure (5).

This means that the lipase production begins in early stage of fungal growth and continues during the period of incubation. The production of lipase during the early stage may help the organism in the degradation of fat and liberating fatty acids which are utilized as nutritional factor or enriched supplements to fungal growth Cultured with Aspergillus oryzae (T4) after 3 days of incubation at $30^{\circ} \mathrm{C}$. 
Table (1): Lipase production ability, of the fungal isolates

\begin{tabular}{|c|c|c|c|}
\hline & Code of isolates & Lipolytic activity & Genera \\
\hline 1 & G10 & ++ & Aspergillus \\
\hline 2 & P3 & + & Aspergillus \\
\hline 3 & T5 & + & Aspergillus \\
\hline 4 & A.p.4 & +++ & Aspergillus \\
\hline 5 & A.ochra & ++ & Aspergillus \\
\hline 6 & $\mathrm{~T} 2$ & +++ & Aspergillus \\
\hline 7 & L17 & ++ & Aspergillus \\
\hline 8 & $\mathrm{H} 1$ & +++ & Aspergillus \\
\hline 9 & M2 & ++ & Aspergillus \\
\hline 10 & L9 & + & Aspergillus \\
\hline 11 & S1 & +++ & Aspergillus \\
\hline 12 & $\mathrm{~T} 4$ & +++ & Aspergillus \\
\hline 13 & $\mathrm{Sb} 2$ & ++ & Aspergillus \\
\hline 14 & T3 & + & Aspergillus \\
\hline 15 & $\mathrm{R} 2$ & +++ & Aspergillus \\
\hline 16 & $\mathrm{P} 25$ & + & Aspergillus \\
\hline 17 & $\mathrm{~T} 1$ & +++ & Aspergillus \\
\hline 18 & $\mathrm{H} 2$ & + & Aspergillus \\
\hline 19 & $\mathrm{~K} 2$ & +++ & Aspergillus \\
\hline 20 & D9 & + & Aspergillus \\
\hline 21 & $\mathrm{Tz}$ & +++ & Aspergillus \\
\hline 22 & L11 & +++ & Aspergillus \\
\hline 23 & $\mathrm{R} 4$ & ++ & Aspergillus \\
\hline 24 & A.p.3 & +++ & Aspergillus \\
\hline 25 & A.p. 5 & + & Aspergillus \\
\hline 26 & A.p.18 & +++ & Aspergillus \\
\hline 27 & 4 & +++ & Aspergillus \\
\hline 28 & Asp & +++ & Aspergillus \\
\hline 29 & I & +++ & Aspergillus \\
\hline 30 & 25.M.E.a & +++ & Aspergillus \\
\hline 31 & Asp.H. & +++ & Aspergillus \\
\hline
\end{tabular}




\begin{tabular}{|l|l|l|l|}
\hline 32 & 2. M.E.A & +++ & Aspergillus \\
\hline 33 & Fus.1 & + & Fuzarium \\
\hline 34 & Fus.2 & ++ & Fuzarium \\
\hline 35 & P.18 & ++ & Penicillum \\
\hline 36 & P.12 & ++ & Penicillum \\
\hline 37 & Pen.3. & +++ & Penicillum \\
\hline 38 & Pen3.4 & + & Penicillum \\
\hline 39 & Pen.H.B.1 & ++ & Penicillum \\
\hline 40 & Pen.C. & ++ & Penicillum \\
\hline 41 & Pen.A. & +++ & Penicillum \\
\hline 42 & Pen.1. & +++ & Penicillum \\
\hline 43 & 3.1 & + & Penicillum \\
\hline 44 & R1 & + & Rhizopus \\
\hline 45 & R3 & Rhizopus \\
\hline
\end{tabular}

Lipolytic activity : + Little precipitation ++ Modrate ppt +++ Dense ppt.

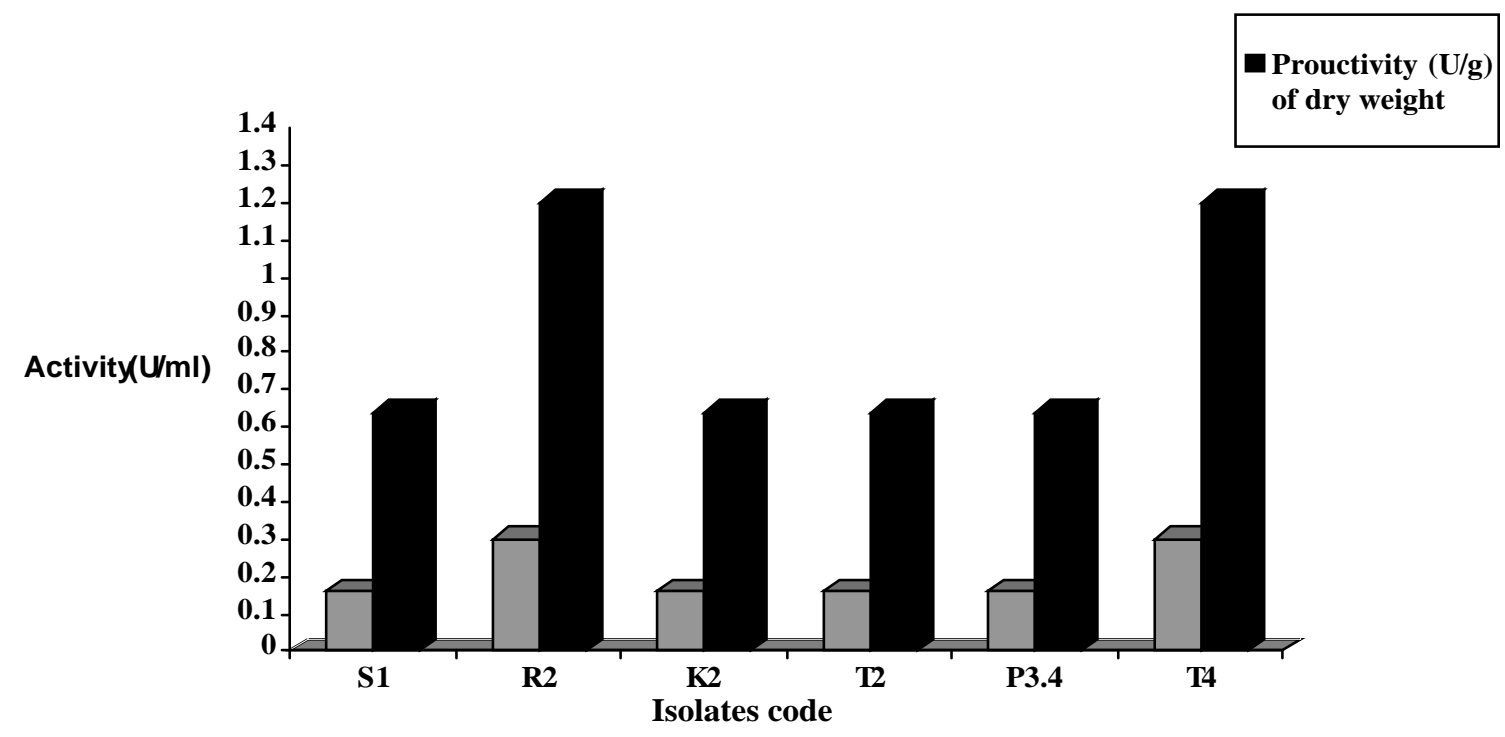

Figure (1): The productivity of lipase from different fungal isolates in wheat bran medium hydrated with tap water 1:3 (w/v) at pH 7.0 . 
Table (2): The growth and ability of isolates for lipase production at different $\mathrm{pH}$

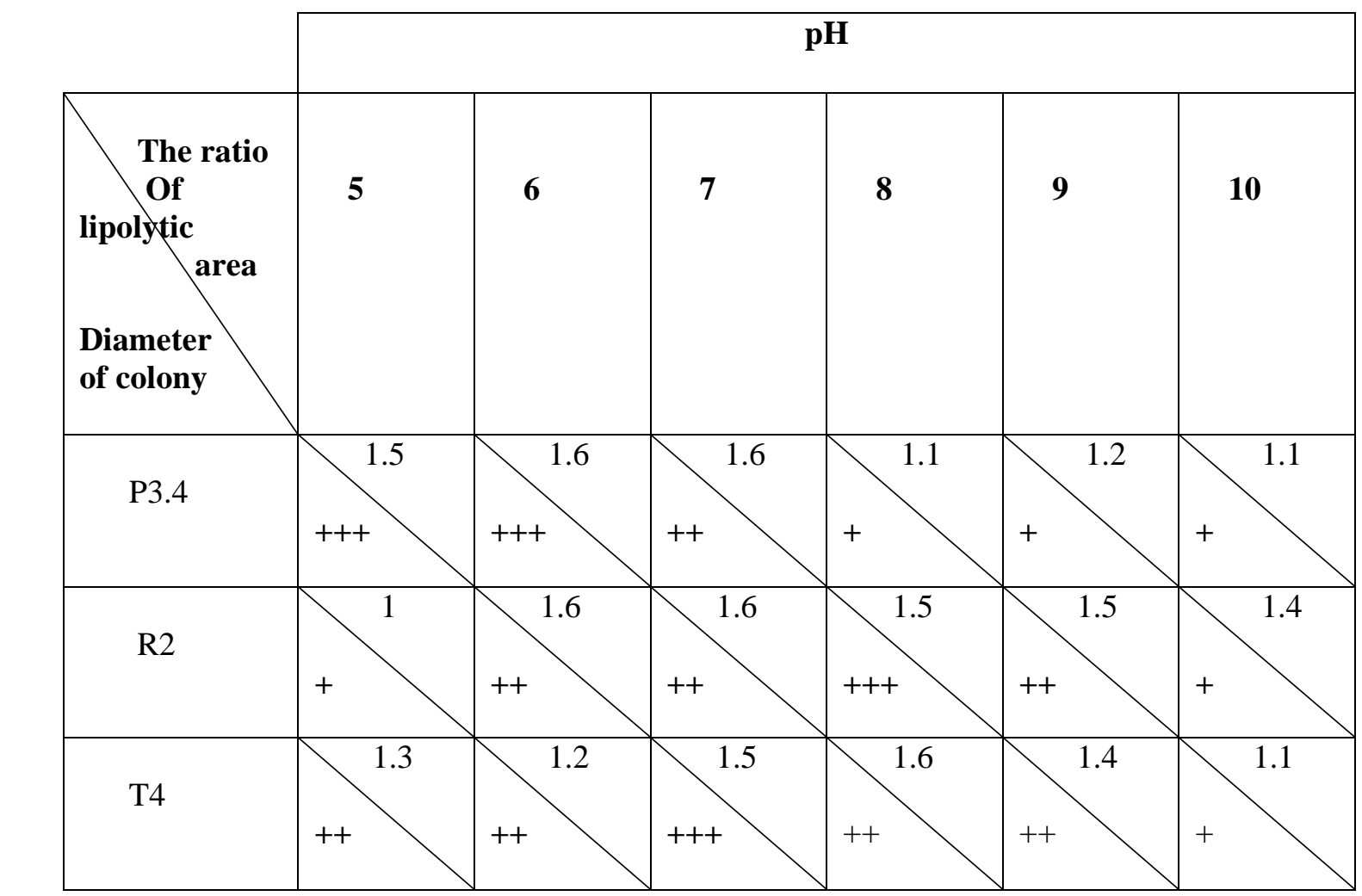

* Colony diameter $:+\leq 1 \mathrm{~cm}++\leq 2 \mathrm{~cm}+++\leq 3 \mathrm{~cm}$ 
Table (3):Growth and ability of isolates for lipase production at different Temperatures, pH 7.0 for 72 hrs.

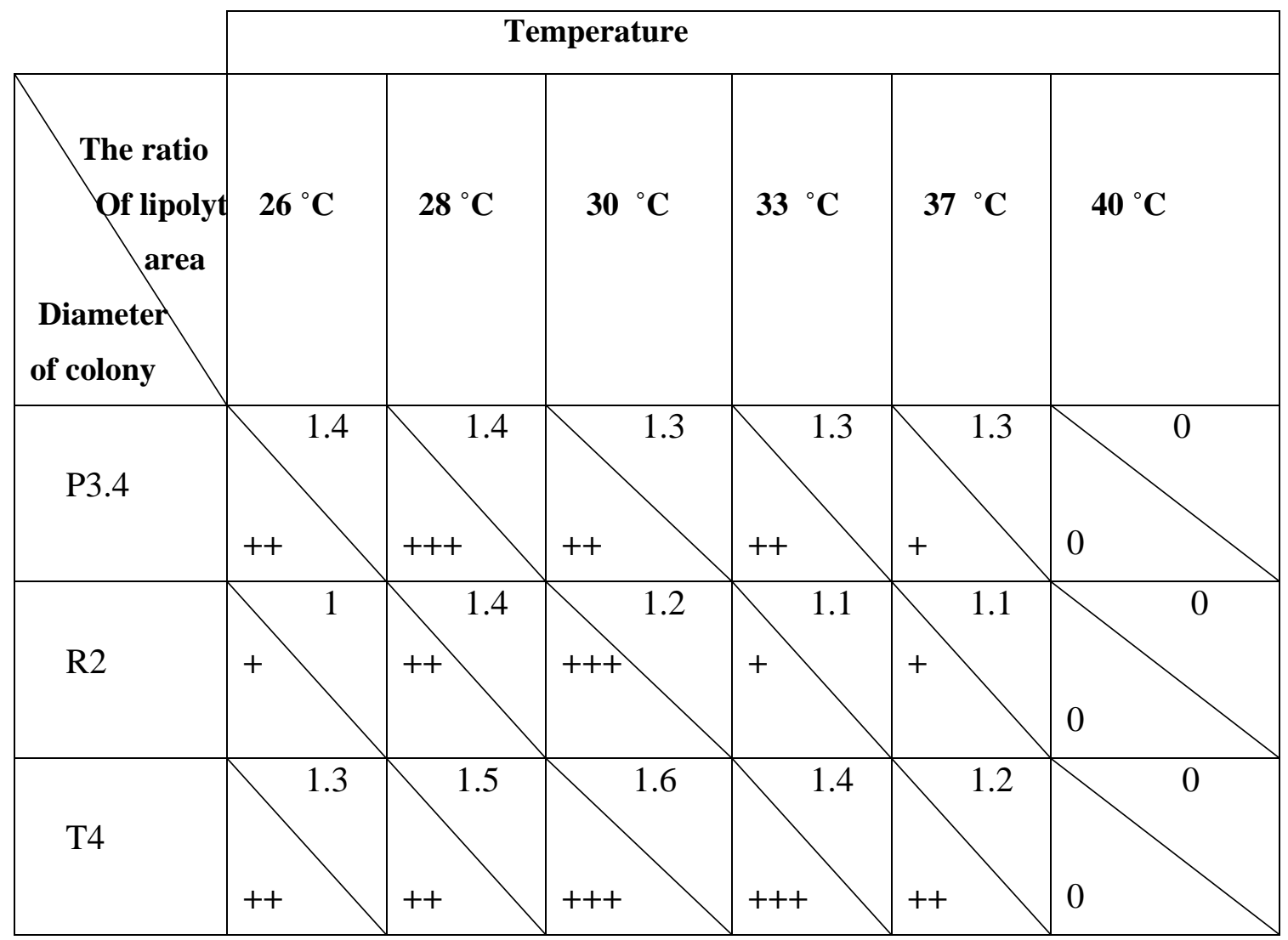

* Colony diameter: $+\leq 1 \mathrm{~cm}++\leq 2 \mathrm{~cm}+++\leq 3 \mathrm{~cm}$

Productivity (U/g) of dry weight

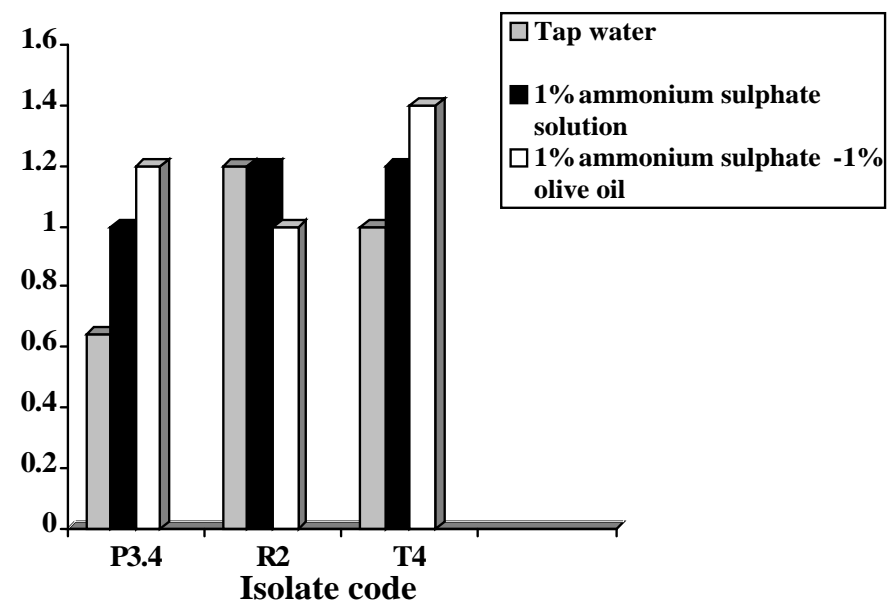

Figure(2): Lipase productivity in wheat bran medium hydrated with diffrenet solution in a ratio of $1: 3(\mathrm{w} / \mathrm{v})$, pH 7.0 inoculated with $10^{5}$ spores/g and incubated at $30 c^{\circ}$ for 3 days. 


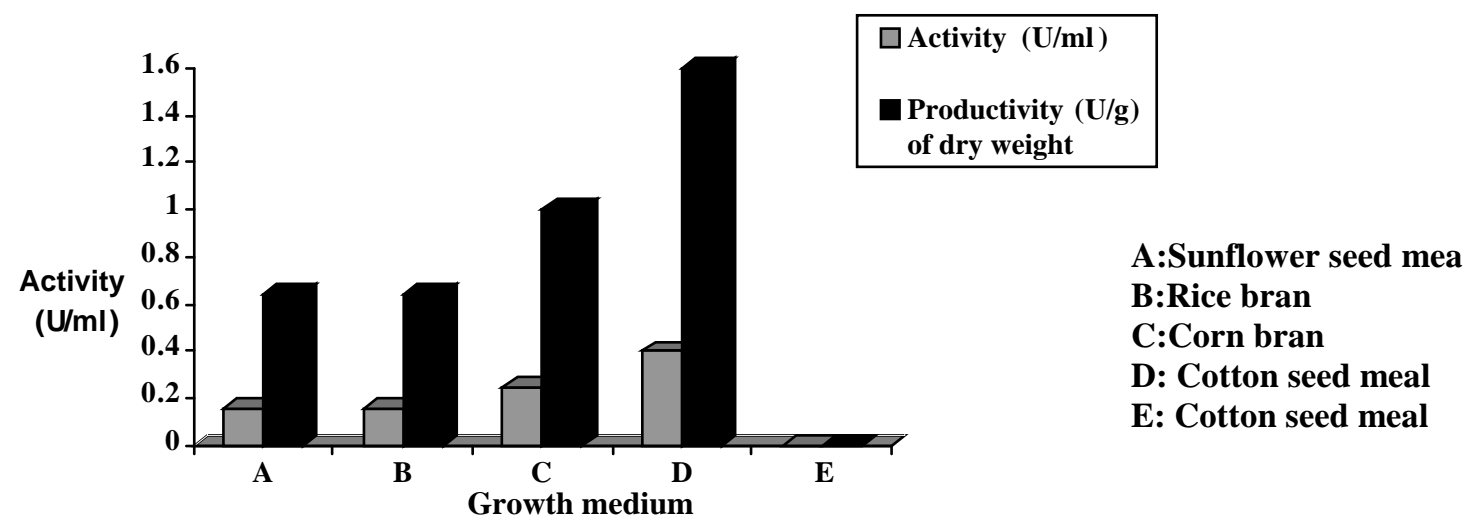

Figure (3):Lipase productivity from Aspergillus oryzae (T4) in different growth media hydrated with $1 \%$ ammonium sulphate $1 \%$ olive oil at ratio of $1: 3(\mathrm{w} / \mathrm{g}), \mathrm{pH} 7.0$ inoculated with $10^{5}$ spores and incubated at $30^{\circ} \mathrm{c}$ for 3 days.

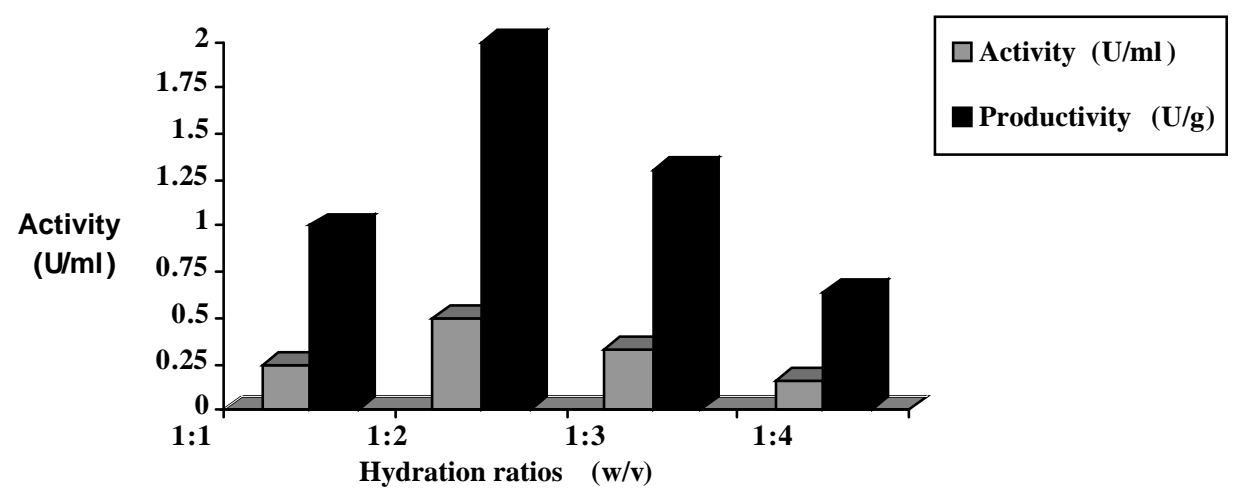

Figure (4): lipase production in cotton seed meal hydrated with different hydration ratios 


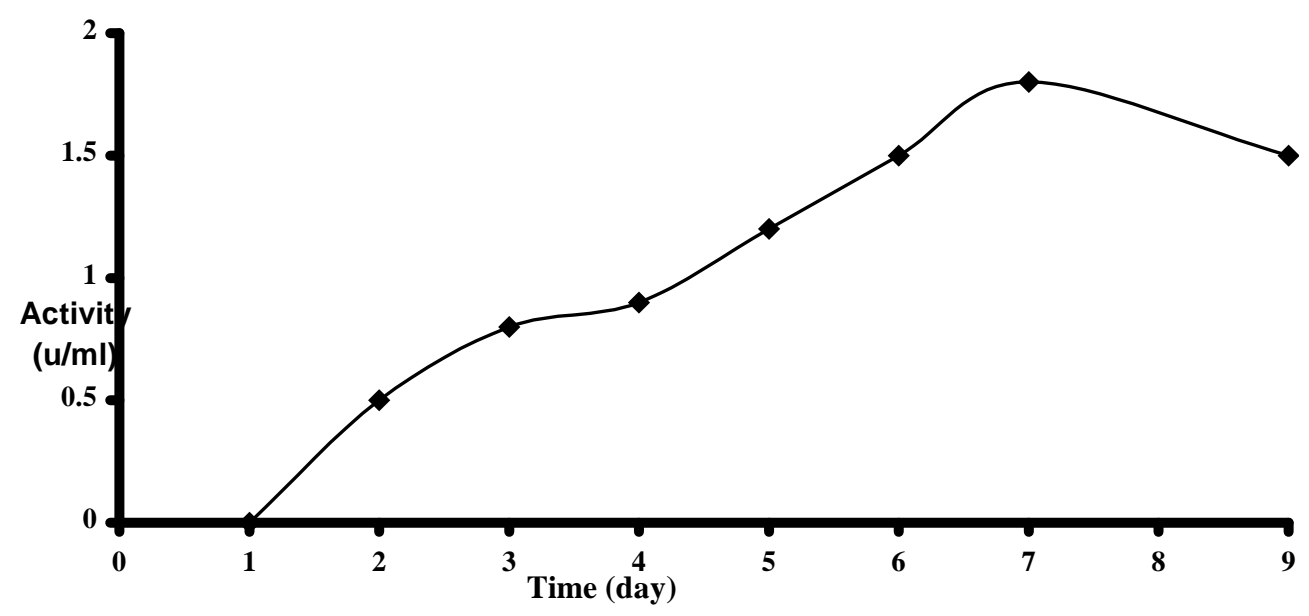

Figure (5): Production of lipase from A. oryzae (T4) during different incubation periods at $30{ }^{\circ} \mathrm{C}$.

\section{3-7 Extraction solution}

The best extraction solution for lipase from cotton seed meal medium was phosphate buffer at $\mathrm{pH} 7.0$ and phosphate buffersodium chlorid solution, the activity in these solution reached to $(0.7 \mathrm{U} / \mathrm{ml})$, followed by sodium chlorid solution $(0.6 \mathrm{U} / \mathrm{ml})$ while the activity reached $(0.5 \mathrm{U} / \mathrm{ml})$ when the enzyme was extracted with tap water figure (6) .
The efficiency of phosphate buffer in enzyme extracton may belong to its ability to dissolve the enzyme and maintains a suitable $\mathrm{pH}$ for the stability of enzyme.

The decreasing in lipolytic activity with tap water may be due to that the tap water has no buffering capacity and ionic strength which facilitate the extraction of enzyme from the medium.

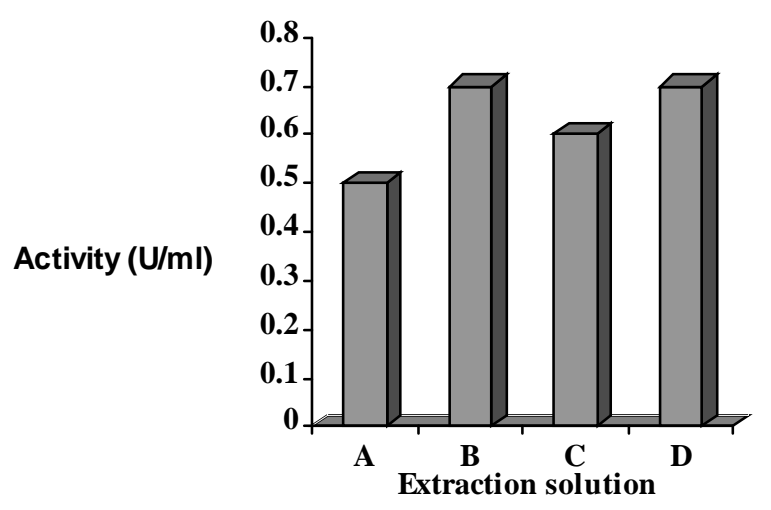

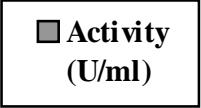
A: Tap water
B: 0.2M phospha buffer pH 7.0
C: $0.2 \mathrm{M}$ sodium chloride solution
D: 0.1M phosphate buffer-0.1M
Sodium chloride solution pH 7.0

Figure (6): Activity of lipase produced by Aspergillus oryzae (T4) growing in cotton seed meal medium and extracted with different extractior colntions 


\section{References}

1. Ionita, A.; Moscovici, M.Dracolici.A.; Eremia, M.; Buca,C. and Albulescu,R.(2001). Lipase production in discontinuous operation system using a Candida lipolytica strain. Roum. Biotechnol. Lett. 7(1): 547-552.

2. Alhir, S.; Markais, P. and Chandan, R.(1990). Lipase of Penicillium caseicolum . J.Agric. Food Chem. 38: 598-60.

3. Nigam, P. and Singh, D.(1994). Solid state (substrate) fermentation systems and their applications in biotechnology. J. Basic Microbiol. 34(6):405-459.

4. Price, N. and Stevens, L.(1982). Fundamentals of Enzymology. Oxfored University Press. New York.

5. Rodina, A.G.(1972). Methods in Aquatic Microbiology. University Perk Press. Baltimore Butter Worts, London.

6. Bier, M.(1955). Lipase. In: Method in Enzymology (eds. Colowish, S. and Kaplan, N.) .Vol.1:627-642. Academic Press. New York.

7. Grajek, W.(1987).Comparative studies on the production of cellulases by thermophilic fungi in submerged and solid-state fermentation. Appl. Microbiol. Biotechnol. 26:126-129.

8. Pandy, A.(1991). Effect of particle size of substrate on enzyme production in solid state fermentation. Bioresource Technol. 37: 169-172.

9. Malathi, S. and Chakraborty (1991).

Production of alkaline protease by new Aspergillus flavus isolate under solid Appl. Enviro. 39 (2): 430-435.

10. Rivera-munoz, G.; Tinoco-valencia, J.; Sanchez, S. and Farres, A.(1991). Production of microbial lipases in a solid state fermentation system. Biotechnol. Lett. 13(4):277-280.

11. Bull, A.T. and Bushnell, M.E.(1976). Environmental control of fungal growth. In: The Filamentous Fungi. (eds. J.E. Smith and D.R. Berry ). Vol.2:1-26 Edward Arnold .London.

12. Stanbury, P.F. and Whitaker, A. (1984). Principles of Fermentation Technology. Led Pregamon Press Ltd., U.K.

13. Maia, M.; Heasley, A.;Morais ,M. and Melo, E.(2001). Effect of culture condition on lipase production by Fusarium solani in batch fermentation. Bioresources Technol. 67:23-27.

14. Domsch, K.H.; Grams,W. and Anderson, T.H.(1980). Compenedium of Soil Fungi. Vol.1. Academic Press. London.

15. Smith, J.E. and Berry, D.R. (1975) . The Filamentous Fungi Vol.1. Edward Arnold .London. 
16. Taylor, M.J. and Richardson,

T.(1979).Application of microbial enzyme in food system and biotechnology. Adv.

Appl. Microbiol 25:7-31. 